\title{
URGENSI SOSIALISASI PEMILU BAGI PEMILIH PEMULA
}

\author{
Setyowati Karyaningtyas \\ Progam Studi Ilmu Administrasi Publik \\ STIA Pembangunan Jember \\ *Email: Tyas.Nugroho17@gmail.com
}

\begin{abstract}
ABSTRAK
Pemilu tahun 2019 ini disebut sebagai Pemilu paling ruwet di seluruh dunia mengingat pemilihan anggota legeslatif serta Presiden dan Wakil Presiden dilakukan secara serentak berdasarkan amanah Undang-Undang Nomor 7 Tahun 2017. Di Negara berkembang termasuk Indonesia apatisme pemilih pemula dari tahun ke tahun kian meningkat. Hal ini sangat kontras dengan cita-cita reformasi yang membuka peluang besar untuk kebebasan berpendapat dan akses informasi bagi masyarakat. Selain itu, suara pemilih pemula ini juga rawan dimanfaatkan oleh oknum-oknum yang sering menggunakan kampanye hitam untuk mendulang suara karena mereka belum memiliki literasi politik yang memadai dan cenderung mengikuti tren di lingkungan tempat tinggalnya. Di tataran desa yang notabene tidak tersentuh sama sekali meskipun sudah ada himbauan dari KPU Pusat hingga Kabupaten/Kota untuk melakukan sosialisasi. Suara milenial mempunyai sumbangsih yang cukup besar pada Pemilu tahun 2019 bahkan disinyalir suara ini mampu mendudukkan 25 anggota dewan di kursi DPR RI, sehingga banyak oknum dan peserta Pemilu yang menggunakan segala cara untuk merebut simpati kaum milenial. Di satu sisi, orientasi politik pemilih pemula ini selalu dinamis dan akan berubah-ubah mengikuti kondisi yang ada, sehingga urgent sekali edukasi politik bagi mereka agar dapat menggunakan hak pilihnya dengan baik dan benar berdasarkan pertimbangan-pertimbangan yang matang dan tidak bersifat pragmatis.
\end{abstract}

Kata kunci: Edukasi Politik, Pemilu, Pemilih Pemula 


\section{Analisis Situasi}

Pada 17 April 2019 bangsa Indonesia akan melakukan pemilihan umum (Pemilu) yang disebut Pemilu yang paling rumit di dunia karena sejak adanya Undang-Undang Nomor 7 Tahun 2017 Pemilu pada tahun 2019 dilakukan serentak untuk memilih DPR, DPD, DPRD dan Pilpres. Keputusan pelaksanaan Pemilu secara serentak ini berawal dari permohonan uji materi UndangUndang Nomor 42 Tahun 2008 tentang Pemilihan Presiden dan Wakil Presiden. Mahkamah Konstitusi pun menyetujui pelaksanaan Pemilu Serentak melalui Putusan Mahkamah Konstitusi Nomor 14/PUU-XI/2013 bahwa pengadaan pemilu legislatif dan presiden yang terpisah bertentangan dengan Undang-Undang Dasar 1945, sehingga tidak bisa dijadikan dasar penyelenggaraan Pemilu. Pemilu serentak ini menimbulkan polemik pagi pemilih yang akan menggunakan hak pilihnya, apalagi bagi pemilih pemula yang notabene belum mempunyai pengalaman untuk hal ini.
Menurut Undang-Undang No. 10 tahun 2008 dalam Bab IV pasal 19 ayat 1 dan 2 serta pasal 20 menyebutkan bahwa yang dimaksud dengan pemilih pemula adalah warga Indonesia yang pada hari pemilihan atau pemungutan suara adalah Warga Negara Indonesia yang sudah genap berusia 17 tahun dan atau lebih atau sudah/pernah kawin yang mempunyai hak pilih, dan sebelumnya belum termasuk pemilih karena ketentuan Undang-Undang Pemilu. Selain itu, pemilih pemula juga disematkan pada anggota TNI Polri yang sudah pensiun. Hal ini didasarkan pada Pasal 28 UU Nomor 2 Tahun 2002 tentang Polri yang menyatakan bahwa "Polri bersikap netral dalam kehidupan politik dan tidak melibatkan diri pada kegiatan politik praktis serta tidak menggunakan hak memilih dan dipilih. Kemudian, disebutkan juga bahwa anggota Polri dapat menduduki jabatan di luar kepolisian setelah mengundurkan diri atau pensiun dari dinas kepolisian". Sementara dalam Pasal 39 Ayat 2 UU Nomor 34 Tahun 2004 tentang TNI, menyebutkan bahwa Prajurit 
dilarang terlibat dalam kegiatan politik praktis. Dalam UU yang sama, Pasal 47 Ayat 1 juga menegaskan bahwa Prajurit hanya dapat menduduki jabatan sipil setelah mengundurkan diri atau pensiun dari dinas aktif keprajuritan ${ }^{1}$.

Dalam kajian ini difokuskan pada definisi pemilih pemula yang pertama yakni mereka yang baru pertama kali menggunakan hak pilihnya karena faktor usia (17 tahun ke atas). Di banyak Negara, tercatat bahwa partisipasi politik pemilih pemula lebih rendah dibandingkan generasi yang lebih tua. Pada kasus yang ada di Indonesia, misalnya mencatat jumlah non-voter (biasa disebut golongan putih atau golput) yang terutama didominasi oleh kaum muda, terus meningkat dari pemilu ke pemilu berikutnya; $10,21 \%$ pada Pemilu 1999, meningkat menjadi 23,34\% pada Pemilu 2004, dan 39,10 $\%$ pada Pemilu 2009, dan 43,23\% pada tahun $2014^{2}$. Hal ini berbanding

${ }^{1}$ https://nasional.kompas.com/read/2018/01/ 19/07395581/bertabrakan-dengan-uu-tnidan-polri-uu-pilkada-perlu-direvisi

2 Sodikin et al 2013 dalam Loina Lalolo Krina Perangin-angin dan Munawaroh Zainal. 2018. Partisipasi Politik Pemula dalam Bingkai Jejaring Sosial di Media terbalik dengan terbukanya akses informasi dan kebebasan berpendapat sejak munculnya era reformasi pada tahun 1998.

Kaum muda adalah kaum yang sulit didikte, bahkan ada dugaan generasi muda merupakan salah satu kelompok yang sulit didekati partai politik ataupun kontestan Pemilu³. Pada umumnya pemilih pemula belum memiliki literasi politik yang memadai dan cenderung mengikuti tren di lingkungan tempat tinggalnya. Pemilih pemula khususnya remaja mempunyai nilai kebudayaan yang santai, bebas, dan cenderung pada hal-hal yang informal dan mencari kesenangan, oleh karena itu semua hal yang kurang menyenangkan akan dihindari ${ }^{4}$. Pemilih pemula memiliki antusiasme yang tinggi sementara keputusan pilihan belum bulat, sebenarnya menempatkan pemilih pemula sebagai swing voters yang

Sosial. Jurnal ASPIKOM, Volume 3 Nomor 4, Januari 2018, hlm 737-754

${ }^{3}$ Rusli, M. Karim. 1991. Pemilu Demokratis Kompetitif. Tiara Wacana. Yogyakarta.

4 Suhartono. 2009. Tingkat kesadaran Politik Pemilih Pemula dalam Pilkada; suatu Refleksi School-Based democracy Education (Studi Kasus Pilkada Provinsi Banten Jawa Barat). UPI. Bandung. 
sesungguhnya. Pilihan politik mereka belum dipengaruhi motivasi ideologis tertentu dan lebih didorong oleh konteks dinamika lingkungan politik lokal. Seringkali apa yang mereka pilih tidak sesuai dengan yang diharapkan. Ketidaktahuan dalam soal politik praktis, terlebih dengan pilihan-pilihan dalam Pemilu atau Pilkada, membuat pemilih pemula sering tidak berpikir rasional dan lebih memikirkan kepentingan jangka pendek.

Oleh karena itu, dalam kegiatan pengabdian masyarakat kali ini dilakukan sosialisasi Pemilu bagi pemilih pemula di SMK Asrama Pembina Masyarakat. SMK ini terletak di jalan. KH. Abdul Hamid Nomor 28-30 Dusun Darussalam, Desa Jatimulyo, Kecamatan Jenggawah, Kabupaten Jember. Sekolah ini didirikan pada tanggal 15 Mei 2008 berdasarkan No. SK. 421.5/392.6/436.41.6/2008 dari Kementrian Pendidikan dan Kebudayaan Indonesia. Sekolah ini mengusung visi Mencetak lulusan yang agamis, saintis, profesional, mandiri dan berakhlaq mulia ${ }^{5}$.

Pengabdian kali ini difokuskan bagi siswa kelas XII karena mereka sudah berusia 17 tahun dan baru pertama kali menggunakan hak pilihnya di tahun 2019 ini. Pemilih pemula disinyalir mempunyai sumbangsih besar dalam perolehan suara, bahkan salah satu pasangan calon Presiden dan Wakil Presiden mengklaim yakin memenangkan Pemilu karena telah mendapat dukungan dari kaum milineal. Agaknya hal ini bukan mustahil karena berdasarkan data dari Dirjen Dukcapil Zudan Arif Farullah menyebutkan, dalam Daftar Penduduk Pemilih Potensial Pemilu (DP4) terdapat pemilih pemula yang akan berusia 17 tahun tanggal 1 Januari 2018 sampai dengan 17 April 2019 sebanyak 5.035.887 jiwa. Jawa Timur sendiri menepati urutan kedua dengan jumlah pemilih pemula terbanyak setelah Provinsi Jawa Barat dengan total pemilih 174.558 jiwa dari

${ }^{5} \mathrm{http} / / /$ smkapmjatimulyo.blogspot.com/2015 110/profil-sekolah.html\# 
DPT 30.554.761 jiwa per 30 Agustus 2018.

Hal ini semakin menjelaskan bahwa suara milenial atau pemilih pemula ini cukup besar di Provinsi Jawa Timur. Di Kabupaten Jember sendiri terdapat 35.000 suara pemilih pemula. Jumlah siswa kelas XII ada 28 dan sekitar 13 orang berasal dari luar Kabupaten, luar Provinsi, bahkan ada yang berasal dari luar pulau sehingga dengan adanya kegiatan sosialisasi Pemilih Pemula ini diharapkan dapat menjadi pembelajaran politik bagi siswa karena mereka belum pernah mendapatkan sosialisasi dari KPU Kabupaten Jember terkait Pemilu, sehingga penting dilakukan sosialisasi pemilih pemula dengan harapan mereka akan mendapatkan edukasi terkait tata cara memilih dan menggunakan hak pilihnya meskipun tidak pulang ke kampung halamannya. Selain itu, sosialisasi ini penting dilakukan mengingat tingginya apatisme milenial dalam bidang politik.

\section{Landasan Teori}

\section{II.1. Pemiihan Umum}

Pemilihan Umum merupakan proses politik untuk memilih orangorang yang akan menduduki jabatan politik di lembaga eksekutif maupun legislatif". "Pemilu juga dapat diartikan sebagai "mekanisme penyeleksian dan pendelegasian atau penyerahan kedaulatan kepada orang atau partai yang dipercayai" ${ }^{7}$. Pemilu diselenggarakan oleh sebuah Negara yang menganut paham demokrasi karena kekuasaan tertinggi ada di tangan rakyat. Pemilu dilakukan dengan mengusung azaz langsung, umum, bebas, rahasia, jujur, dan adil.

Berdasarkan Undang-Undang Nomor 8 tahun 2012 Pasal 3, Pemilu bertujuan memilih anggota DPR, DPRD Provinsi dan DPRD Kabupaten/Kota dalam NKRI berdasarkan Pancasila dan UUD 1945. Pemilu juga berfungsi sebagai alat demokrasi untuk tiga hal: 1) Mempertahankan serta mengembangkan sendi demokrasi di

${ }^{6}$ Ike Atikah Ratnamulyani dan Beddy Iriawan Maksudi. 2018. Peran Media Sosial dalam Peningkatan Partisipasi Pemilih Pemula di Kalangan Pelajar di Kabupaten Bogor. Sosiohumaniora - Jurnal Ilmu-ilmu Sosial dan Humaniora. Vol. 20, No. 2, Juli 2018: 154 - 161

7 Surbakti, Ramlan. 1992. Memahami Ilmu Politik. Jakarta: Gramedia Widya Sarana 
Indonesia. 2) Mewujudkan masyarakat yang adil dan makmur berdasarkan Keadilan sosial bagi seluruh rakyat Indonesia). 3) Menjamin tetap tegaknya Pancasila dan dipertahankannya UUD $1945^{\circ}$.

\section{II.2. Pemilih Pemula}

Pemilih pemula dalam konteks ini lebih merujuk pada WNI yang berumur 17 - 21 pada saat Pemilu diadakan. Menurut Undang-Undang No. 10 tahun 2008 dalam Bab IV pasal 19 ayat 1 dan 2 serta pasal 20 menyebutkan bahwa pemilih pemula adalah warga Indonesia yang pada hari pemilihan atau pemungutan suara adalah Warga Negara Indonesia yang sudah genap berusia 17 tahun dan atau lebih atau sudah/pernah kawin yang mempunyai hak pilih, dan sebelumnya belum termasuk pemilih karena ketentuan Undang-Undang Pemilu. Pemilih pemula dalam kategori politik adalah kelompok yang baru pertama kali menggunakan hak pilihnya 9 .

${ }^{8}$ C.S.T. Kansil dan Christine S.T. Kansil ${ }^{9}$ Wardani, Primandha Sukma Nur, Partisipasi Politik Pemilih Pemula dalam
Orientasi politik pemilih pemula ini selalu dinamis dan akan berubahubah mengikuti kondisi yang ada karena jiwa mereka masih labil akibat adanya faktor-faktor yang mempengaruhinya. Siapapun yang dapat merebut perhatian kalangan ini, maka dapat merasakan keuntungannya, begitu juga sebaliknya karena jika tidak ada dukungan kalangan ini akan terasa cukup merugikan bagi target-target suara pemilihan yang ingin dicapai.

\section{Identifikasi dan Perumusan}

\section{Masalah}

Berdasarkan uraian di atas, ada dua permasalahan yang dirumuskan yaitu:

a. bagaimana kiprah pemilih pemula dalam Pemilu tahun 2019?.

b. mengapa penting dilakukan sosialisasi pemilu bagi pemilih pemula?.

\section{Tujuan dan Manfaat Program}

Pemilihan Umum. Jurnal Pendidikan IlmuIlmu Sosial, 10 (1): 57-62. 
Tujuan pengabdian masyarakat ini secara umum ada dua yaitu:

1. memberikan pendidikan politik bagi pemilih pemula sehingga nantinya mereka dapat memberikan hak suara secara baik dan benar karena mereka baru pertama kali menggunakan hak pilihnya;

2. memberikan dorongan dan edukasi pada pemilih pemula terkait arti pentingnya berpartisipasi dalam pesta demokrasi mengingat pemilih pemula mencapai 7.000.000. Hal ini berarti suara pemilih pemula dapat menentukan 35 kursi anggota dewan.

Pemilih pemula ini adalah generasi muda penerus bangsa yang akan menentukan nasib bangsa dan Negara ke depannya, sehingga manfaat yang diharapkan dengan adanya kegiatan sosialisasi dan diskusi ini adalah menjadikan para pelajar ini agar bisa menjadi agen atau pelopor bagi masyarakat umum untuk memberikan pemahaman tentang arti pentingnya menggunakan hak suara pada pemilu secara baik dan benar. Oleh karena itu semangat nasionalisme perlu kita tingkatkan pada generasi muda dengan harapan bangsa kita dapat menjadi bangsa yang lebih baik lagi dengan mengoptimalkan kesadaran pemilih pemula dalam Pemilu tahun 2019.

\section{Bentuk Kegiatan}

Bentuk kegiatan program pengabdian masyarakat ini adalah sosialisasi dan diskusi yang dilakukan di SMK Asrama Pembina Masyarakat Desa Jati Mulyo, Kecamatan Jenggawah, Kabupaten Jember. Dalam sosialisasi ini kami memaparkan tentang pengertian Pemilu, dasar hukum pelaksanaan Pemilu, asas Pemilu, prinsip Pemilu, siapa pemilih pemula itu, hal yang perlu diperhatikan saat memilih, pengenalan partai politik peserta Pemilu, pengenalan surat suara Pemilu yang terdiri dari lima surat suara, kendala dan solusi yang dihadapi pemilih pemula saat menggunakan hak pilihnya, dan yang 
terakhir adalah pemutaran video tata cara menggunakan hak pilih saat menyoblos di TPS.

Kegiatan diskusi antara pemateri dengan kelompok sasaran terjadi sangat intens dalam artian siswa kelas XII SMK Asrama Pembina Masyarakat sangat antusias dan pro- aktif untuk berdiskusi terkait hal-hal Pemilu. Pertanyaan yang dilontarkan oleh siswa dalam kegiatan ini ada tiga, yaitu:

1. bagaimana jika kami tidak mempunyai E- KTP ketika ingin menyalurkan hak pilih? Dari dari 25 peserta, hanya 14 siswa yang memiliki EKTP sehingga 11 siswa terancam kehilangan hak pilihnya.

2. bagaimana nasib siswa yang berasal dari luar pulau Jawa ketika Pemilu?. Apakah masih dapat menggunakan hak pilihnya mengingat siswa tersebut tidak bisa pulang ke kampung halamnnya?.

3. Bagaimana caranya agar kita dapat memilih wakil rakyat yang amanah serta benarbenar bekerja untuk rakyat?.

\section{Pelaksanaan Program}

Sosialisasi ini dilaksanakan pada hari Jumat tanggal 22 Maret pukul 09.00 - 12.00 di SMK Asrama Pembina Masyarakat Desa Jatimulyo Kecamatan Jenggawah Kabupaten Jember dengan jumlah peserta 25 siswa. Kegiatan sosialisasi ini bertepatan dengan diadakannya Kuliah Kerja Nyata mahasiswa STIA "Pembangunan" tahun 2019 di Desa Jatimulyo yang juga merupakan tahun Pemilu, sehingga tepat sekali diadakan sosialisasi dan diskusi tentang pemilih pemula kepada siswa kelas XII SMK Asrama Pembina Masyarakat karena mereka baru pertama kali menggunakan hak pilihnya.

\section{Khalayak Sasaran}

Dalam kegiatan sosialisasi kali ini yang dijadikan target group adalah mereka yang berusia $17-21$ tahun, yakni siswa XII SMK Asrama Pembina Masyarakat Desa Jatimulyo, Kecamatan Jenggawah, Kabupaten Jember. Hal ini dikarenakan pemilih pemula 
terutama yang masih duduk di bangku SMA atau SMK relatif awam terhadap politik, sehingga pilihannya tidak didasari oleh pertimbanganpertimbangan yang terlalu matang dan bahkan banyak pemilih pemula yang apatis terhadap politik sehingga mereka memilih golput. Selain itu, pemilih pemula selalu menjadi sasaran strategis bagi peserta pemilu karena tiga alasan, yakni jumlahnya yang relative besar, harus diberi arahan yang baik sehingga bisa memiliki pemahaman yang baik tentang demokrasi, dan calon pemimpin masa depan ${ }^{10}$.

\section{Evaluasi Kegiatan}

Evaluasi kegiatan dilakukan dengan cara melakukan simulasi pencoblosan surat suara serta Tanya jawab seputar Pemilu untuk mengetahui pemahaman target group. Selain itu, evalusi juga dilakukan dengan cara melihat tingkat partisipasi target group dalam menggunakan hak pilihnya

${ }^{10}$ Mailana, Liyan Putri. 2014. Modul KKN Universitas Diponegoro secara baik dan benar pada Pemilu tahun 2019.

\section{DAFTAR PUSTAKA}

\section{Buku dan Jurnal Ilmiah}

Ike Atikah Ratnamulyani dan Beddy Iriawan Maksudi. 2018. Peran Media Sosial dalam Peningkatan Partisipasi Pemilih Pemula di Kalangan Pelajar di Kabupaten Bogor. Sosiohumaniora - JurnalIImuilmu Sosial dan Humaniora. Vol. 20, No. 2, Juli 2018: 154 - 161

Mailana, Liyan Putri. 2014. Modul KKN Universitas Diponegoro

Rusli, M. Karim. 1991. Pemilu Demokratis Kompetitif. Tiara Wacana. Yogyakarta.

Sodikin et al 2013 dalam Loina Lalolo Krina Perangin-angin dan Munawaroh Zainal. 2018. Partisipasi Politik Pemula dalam Bingkai Jejaring Sosial di Media Sosial. Jurnal ASPIKOM, Volume 3 Nomor 4, Januari 2018, hlm 737-754

Suhartono. 2009. Tingkat kesadaran Politik Pemilih Pemula dalam Pilkada; suatu Refleksi SchoolBased democracy Education (Studi Kasus Pilkada Provinsi Banten Jawa Barat). UPI. Bandung.

Surbakti, Ramlan. 1992. Memahami Ilmu Politik. Jakarta: Gramedia Widya Sarana Rusli, M. Karim. 1991. Pemilu Demokratis Kompetitif. Tiara Wacana. Yogyakarta.

Wardani, Primandha Sukma Nur, Partisipasi Politik Pemilih 
Pemula dalam Pemilihan

Umum. Jurnal Pendidikan Ilmu-

Ilmu Sosial, 10 (1): 57-62.

\section{Peraturan Perundang-Undangan \\ Undang-Undang Dasar 1945 \\ Undang-Undang Nomor 2 Tahun 2002 Tentang Polri \\ Undang-Undang Nomor 34 Tahun 2004 Tentang TNI \\ Undang-Undang Nomor 10 Tahun 2008 Tentang Pemilihan Umum \\ Undang-Undang Nomor 7 Tahun 2017 Tentang Pemilihan Umum \\ Mahkamah Konstitusi Nomor 14/PUU-XI/2013 Tentang Pengujian Undang-Undang Nomor 42 Tahun 2008 Tentang Pemilihan Umum}

\section{Website}

https://nasional.kompas.com/read/20 18/01/19/07395581/bertabrakan-

dengan-uu-tni-dan-polri-uu-pilkadaperlu-direvisi

http://smkapmjatimulyo.blogspot.co

$\underline{\mathrm{m} / 2015 / 10 / \text { profil-sekolah.html\# }}$ 